\title{
Livestock herd structures and dynamics in Garissa County, Kenya
}

\author{
Patrick Mwambi Mwanyumba ${ }^{1 *}$, Raphael Wahome Wahome ${ }^{2}$, Laban MacOpiyo ${ }^{3}$ and Paul Kanyari ${ }^{4}$
}

\begin{abstract}
In Kenya's Northeastern Province, pastoralism is the main livestock production system and means of livelihood. However, pastoralists are facing increasing risks such as drought, insecurity, animal diseases, increasing human populations and land fragmentation. This study sought to evaluate household livestock herd structures and dynamics in view of such risks and subsistence and market demands. The study was conducted in Garissa County of Kenya, using a cross-sectional household survey. The data was analysed for descriptive statistics of household livestock status, dynamics and demographic parameters. The results showed that females of reproductive age formed over $50 \%$ of all livestock species. Cattle had the highest turnover and all species' mortalities accounted for the greater proportion of exits. Cattle had the highest multiplication and growth rates, but also the highest mortality, offtake, commercial offtake and intake rates. Goats had the lowest mortalities, offtake, commercial offtake and intake rates. Overall, the herds were structured to provide for both immediate and future needs in terms of milk, sales and herd replacement as well as for rapid recovery after disasters. The livestock herd dynamics indicate efforts at culling, restocking, retention of valuable categories of animals, and natural events. Livestock populations would be annihilated over time if the trends in end balances and negative growth rates were to continue and not be interrupted by the upward phases of the livestock cycles. It was recommended that the Government and development partners should undertake interventions to balance the herd dynamics in favour of entries by improvement of reproduction and reduction of mortalities, and support livelihood diversification to reduce dependence on livestock.
\end{abstract}

Keywords: Demographic, Distribution, Entries, Inventory, Livestock, Structures

\section{Background}

In Kenya's Northeastern Province, pastoralism is the main means of livelihood and livestock trade consists of indigenous livestock of local and cross-border origin. However, there is worldwide concern on the conservation and utilization of these breeds which are also an important source of genetic diversity that can be used for disease resistance and for coping against climate change (FAO 2007). Aklilu et al. (2002) and Pavanello (2010) reported that growing financial pressures, food insecurity and frequent droughts are increasingly pushing pastoralists to sell more animals than before and regardless of productivity, age or sex.

\footnotetext{
*Correspondence: pm.mwanyumba@yahoo.com

'Department of Veterinary Services, Ministry of Agriculture, Livestock and Fisheries, Private Bag-00625, Nairobi, Kenya

Full list of author information is available at the end of the article
}

Galaty and Aronson (1980) cited the impact of external changes and altered constraints on traditional range practices, the effects of consumer preferences on herd structures and the significance of increased use of the market as some of the pastoralist research priorities. Bailey et al. (1999) noted that variability in herd structures in the Horn of Africa has not been documented in the past and the factors responsible have not been explained though they are suspected to influence availability of market meat animals. The National Livestock Policy (Government of Kenya 2008) documented that the country is currently not self-sufficient in beef and mutton and recommended that appropriate interventions be put in place to avoid deficits in livestock products. This study therefore clarified the livestock herd dynamics and contributing factors.
严 Springer

(c) 2015 Mwanyumba et al. Open Access This article is distributed under the terms of the Creative Commons Attribution 4.0 International License (http://creativecommons.org/licenses/by/4.0/), which permits unrestricted use, distribution, and reproduction in any medium, provided you give appropriate credit to the original author(s) and the source, provide a link to the Creative Commons license, and indicate if changes were made. 


\section{Study area}

The study was undertaken in Garissa County in northeastern Kenya, where pastoralism is the main livestock production system and means of livelihood. Garissa County lies between latitude $1^{\circ} \mathrm{N}$ and $2^{\circ} \mathrm{S}$ and longitude $39^{\circ} \mathrm{E}$ and $41^{\circ}$ $\mathrm{E}$ and borders Somalia to the east, Wajir County to the north, Isiolo County to the north-west, Tana River County to the west and Lamu County to the south. The County lies at an elevation of 1,138 $\mathrm{m}$ above sea level, the area topography is flat and the climate is semi-arid to arid (agro-ecological zone (AEZ) IV-VI). A map of Kenya showing the Arid and Semi-arid Districts is shown in Figure 1.

The annual rainfall ranges from 300 to $700 \mathrm{~mm}$ in two seasons, long rains in March to May and short rains in October to December, often in isolated heavy downpours. Maximum daily temperatures range from $34{ }^{\circ} \mathrm{C}$ between June and August to $38{ }^{\circ} \mathrm{C}$ in February and March. The climate is thus hot and dry with high rates of evapo-transpiration, interspersed with occasional flooding in poorly drained areas.

Garissa County has an area of $44,952 \mathrm{~km}^{2}$ and a human population of 623,060 (Kenya National Bureau of Statistics 2010). The inhabitants are pastoralists and agro-pastoralists keeping camels, cattle, sheep, goats and donkeys and doing some crop farming along the river Tana. The County is the immediate catchment for Garissa livestock market which is the largest in East Africa and serves to supply livestock for both the local market and export.

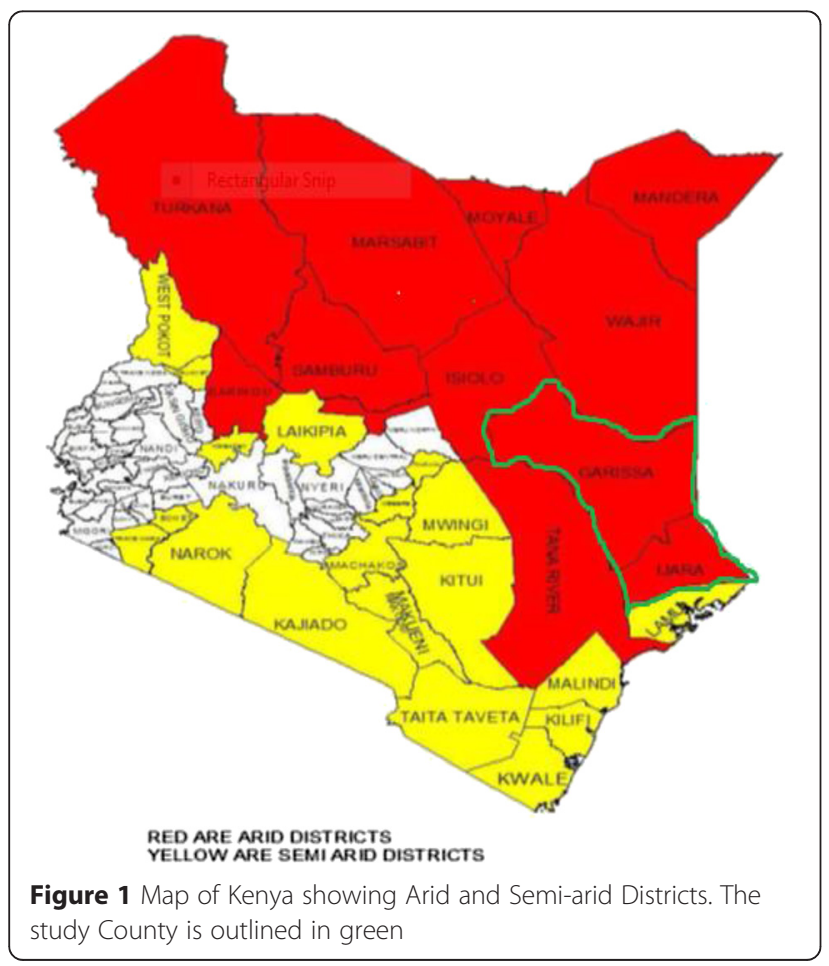

\section{Methods}

\section{Data collection}

One hundred forty-six (146) respondents were interviewed in a cross-sectional survey undertaken in July 2012. Interviewed households were selected from the County using multi-stage cluster sampling technique with random sampling at each level. The calculated sample size was 138 from the formula by Pfeiffer (2010).

The formula:

$$
n=Z^{2}\left[p(1-p) / L^{2}\right]
$$

where

$n=$ the sample size;

$Z=1.96$, the standard normal deviate at the desired confidence interval, $95 \%$;

$p=0.9$ (90\%), the assumed proportion (prevalence) of the households who own livestock and engage with the other segments of the value chain;

$L=0.05$ (5\%), the precision.

The calculation of the sample size is shown below.

$$
\begin{aligned}
\text { Sample size } & =1.96^{2}\left[0.9(1-0.9) / 0.05^{2}\right] \\
& =3.84[0.9(0.1 / 0.0025)] \\
& =3.84[0.9(40)] \\
& =3.84[36] \\
& =138.24
\end{aligned}
$$

The method was applied with the objective of getting at least 144 completed questionnaires using eight enumerators. Three Districts were randomly selected from among five out of seven in the County in the first stage. Two Districts, Fafi and Dadaab, were left out due to security reasons. Three Divisions were randomly selected, one from each of the three Districts, in the second stage and nine locations, three from each Division, in the third stage. Sixteen households were then selected from each of the nine locations by roughly dividing it into imaginary quadrants. Eight enumerators interviewed two randomly selected households in each quadrant daily.

The nine locations selected were Dujis, Jarajara and Balambala in Balambala Division, Balambala District (48 households); Saka, Raya and Shimbir in Sankuri Division, Garissa District (51 households); and Hara, Masalani and Korisa in Masalani Division, Ijara District (47 households). Figure 2 shows an illustration of the multi-stage cluster sampling while Figure 3 is a map of Kenya showing Garissa County and the study areas Balambala, Sankuri and Masalani Divisions.

Data on the herd structures and changes was collected using the retrospective 12-month approach discussed by Lesnoff et al. (2010) which depends on the respondents' recall of events of the preceding 12 months. The 


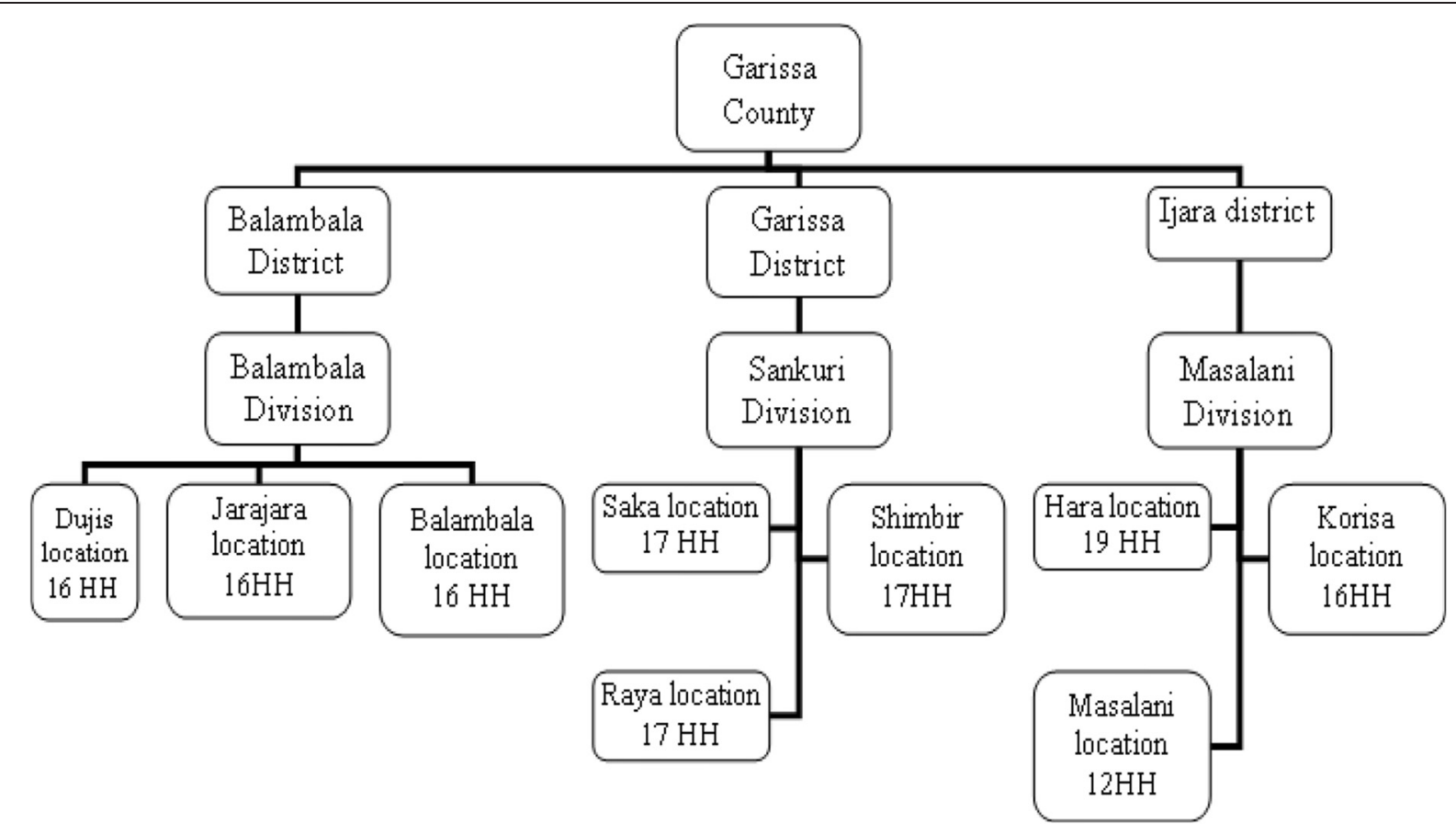

Figure 2 Illustration of the multi-stage cluster sampling $(\mathrm{HH}=$ households)

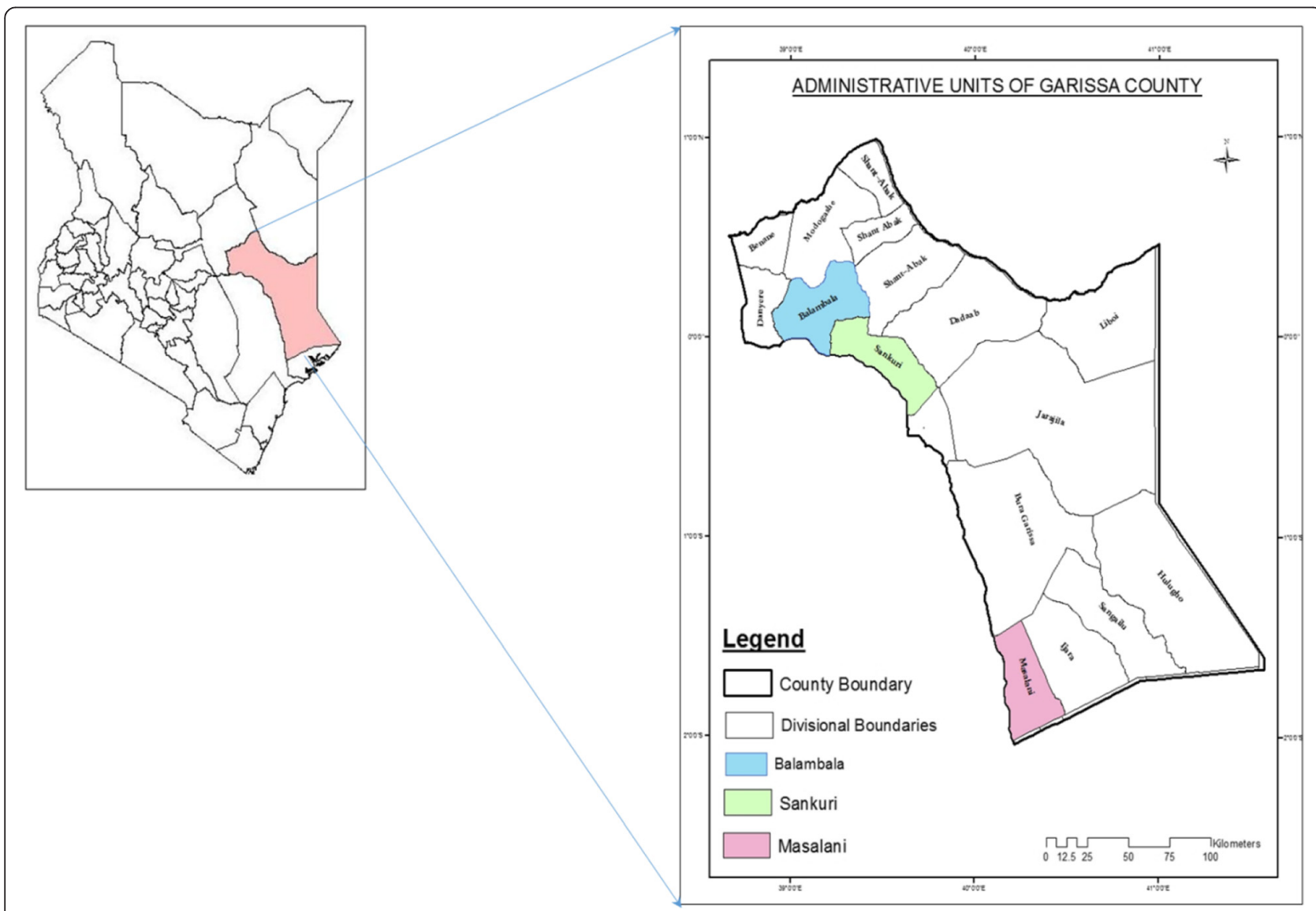

Figure 3 Map of Kenya showing the study areas 
respondents were asked questions on their livestock inventory and the transactions and changes over the preceding 12 months.

\section{Data analysis}

The data was entered into Microsoft Excel 2007 and Statistical Package for the Social Sciences (SPSS) 18 and analysed for descriptive statistics of the livestock inventory and herd structures; herd status and changes, entries and exits; and demographic parameters.

\section{Results}

\section{Livestock inventory and herd structures}

The study area household livestock inventory and herd structure by species, age and sex categories are shown in Table 1. Goats came first, in proportions of total herd size, followed by cattle, sheep, camels and lastly donkeys. Females formed the greater proportion of herds in all species. However, the ratio of males to females was higher than would be expected for purposes of breeding alone. The age trend in male cattle (younger more in herd than older) also contrasted that in females where the older and therefore of proven performance formed the larger proportion. There was a small steers to males ratio in cattle and a relatively high proportion of young stock in all species.

\section{Household livestock herd dynamics}

Table 2 shows the livestock entries and exits by species, sex and age. Exits were more than entries in all species. Cattle had the highest turnover followed by goats, sheep, camels and then donkeys.

In all species, sex and age categories, purchases accounted for the greater proportion of entries followed by births, then in-donations. Mortalities accounted for the greater proportion of exits, followed by sales, outdonations, consumptions and unexplained losses in that order. In all the entry and exit events combined, purchases came first, followed by deaths, sales, births, out-donations, in-donations, consumption and lastly unexplained losses. End balances were negative except for camel female calves, cattle males of 1 to 3 years of age, cattle females of 3 to 6 years of age, cattle female calves, lambs, kids and donkeys.

Table 3 shows variables of the herd that describe their state at the time of the study and over the preceding 12 months. The variables are used to calculate the

Table 1 Households' livestock inventory and herd structures by species, age and sex

\begin{tabular}{|c|c|c|c|c|c|c|c|}
\hline & $N^{a}$ & Min. & Max. & SD & Mean & $\%$ of total & $\%$ of categories \\
\hline Adult male camels & 42 & 1 & 22 & 4.5 & 4.5 & 20.2 & \multirow[t]{2}{*}{ Ratio of males to females $1: 3$} \\
\hline Adult female camels & 55 & 1 & 50 & 12.8 & 11.7 & 52.5 & \\
\hline Camel male calves & 26 & 1 & 13 & 2.4 & 2.7 & 12.1 & \multirow[t]{3}{*}{ All calves $27.3 \%$ of camels } \\
\hline Camel female calves & 34 & 1 & 16 & 3.1 & 3.4 & 15.2 & \\
\hline Total camels and \% in herd & & & & & 22.3 & 10.5 & \\
\hline Steers & 5 & 1 & 6 & 2.0 & 2.8 & 3.9 & \multirow{10}{*}{$\begin{array}{l}\text { Ratio of steers to other males } 1: 8 \text { :Ratio of reproductive males to } \\
\text { reproductive females } 1: 2 \text {;Reproductive females } 37.2 \% \text { of cattle } \\
\text { All calves } 13.8 \% \text { of cattle }\end{array}$} \\
\hline Entire males $>6$ years & 47 & 1 & 50 & 9.7 & 7.0 & 9.9 & \\
\hline Entire males 3 to 6 years & 51 & 1 & 30 & 7.5 & 7.5 & 10.6 & \\
\hline Entire males 13 years & 49 & 1 & 70 & 13.2 & 8.2 & 11.5 & \\
\hline Cows $>6$ years & 83 & 1 & 180 & 31.3 & 16.5 & 23.2 & \\
\hline Cows 3 to 6 years & 66 & 1 & 56 & 12.3 & 9.9 & 13.9 & \\
\hline Female cattle 1 to 3 years & 48 & 1 & 103 & 17 & 9.3 & 13.1 & \\
\hline Male calves & 47 & 1 & 46 & 7.3 & 4.5 & 6.3 & \\
\hline Female calves & 46 & 1 & 69 & 10.4 & 5.3 & 7.5 & \\
\hline Total cattle and $\%$ in herd & & & & & 71 & 33.4 & \\
\hline Ewes & 102 & 1 & 236 & 34.9 & 21.2 & 55.9 & \multirow[t]{5}{*}{ All lambs $24.8 \%$ of sheep; ratio of rams to ewes $1: 3$} \\
\hline Rams & 86 & 1 & 102 & 13.1 & 7.3 & 19.3 & \\
\hline Lambs & 95 & 1 & 126 & 15 & 9.4 & 24.8 & \\
\hline Total sheep and \% in herd & & & & & 37.9 & 17.8 & \\
\hline Does & 137 & 1 & 350 & 60.0 & 50.1 & 63.1 & \\
\hline Bucks & 125 & 1 & 128 & 20.3 & 13.7 & 17.3 & \multirow[t]{5}{*}{ All kids $19.6 \%$ of goats; ratio of bucks to does $1: 4$} \\
\hline Kids & 130 & 1 & 113 & 15.7 & 15.6 & 19.6 & \\
\hline Total goats and \% in herd & & & & & 79.4 & 37.3 & \\
\hline Donkeys and \% in herd & 76 & 1 & 14 & 2.3 & 2.2 & 1 & \\
\hline Total herd & & & & & 212.8 & $100 \%$ & \\
\hline
\end{tabular}

${ }^{a} N^{\prime}$ is the sub-sample size and differs between species and categories because such owning households are less than the sample size of 146 . The numbers also reflect the frequency of ownership. Values in italics indicate the sub-totals of the categories above 
Table 2 Mean annual number of livestock entries and exits by species, sex and age

\begin{tabular}{|c|c|c|c|c|c|c|c|c|c|c|c|c|c|}
\hline \multirow[b]{2}{*}{ Species } & \multirow[b]{2}{*}{ Sex } & \multirow[b]{2}{*}{ Age } & \multicolumn{4}{|c|}{ Entries } & \multicolumn{6}{|l|}{ Exits } & \multirow[b]{2}{*}{ End balance } \\
\hline & & & Born & Bought & Given & Total & Sold & Gave & Ate & Died & Lost & Total & \\
\hline \multirow[t]{4}{*}{ Camels } & Males & Adults & & 1 & 1 & 2 & 2.5 & 1 & 1 & 1.7 & 0 & 6.2 & -4.2 \\
\hline & & Calves & 1.8 & 0 & 0 & 1.8 & 1.8 & 1 & 1.3 & 2 & 0 & 6.1 & -4.3 \\
\hline & Females & Adults & & 2 & 3.7 & 5.7 & 1.9 & 1.3 & 1 & 3.2 & 1.5 & 8.9 & -3.2 \\
\hline & & Calves & 2.3 & 3 & 0 & 5.3 & 1 & 1.5 & 0 & 2.3 & 0 & 4.8 & 0.5 \\
\hline \multirow[t]{9}{*}{ Cattle } & Steers & & & 0 & 0 & 0 & 1.7 & 0 & 0 & 0 & 0 & 1.7 & -1.7 \\
\hline & Males & $\geq 6$ years & & 2.6 & 1 & 3.6 & 2.8 & 1.8 & 1 & 2.1 & 1 & 8.7 & -5.1 \\
\hline & & 3 to 6 years & & 6.7 & 1 & 7.7 & 2.4 & 1.5 & 1.5 & 2.4 & 0 & 7.8 & -0.1 \\
\hline & & 1 to 3 years & & 13.5 & 1 & 14.5 & 1.7 & 1.8 & 1 & 2.4 & 1 & 7.9 & 6.6 \\
\hline & & Calves & 4.4 & 0 & 0 & 4.4 & 6 & 0 & 0 & 1.9 & 0 & 7.9 & -3.5 \\
\hline & Females & $\geq 6$ years & & 2 & 1.6 & 3.6 & 1.6 & 3.3 & 1 & 5.1 & 0 & 11 & -7.4 \\
\hline & & 3 to 6 years & & 10.6 & 1 & 11.6 & 2.6 & 1.5 & 0 & 3.7 & 1 & 8.8 & 2.8 \\
\hline & & 1 to 3 years & & 0 & 1.3 & 1.3 & 1.4 & 1.5 & 0 & 2.8 & 0 & 5.7 & -4.4 \\
\hline & & Calves & 4.9 & 3 & 0 & 7.9 & 0 & 0 & 0 & 1.6 & 0 & 1.6 & 6.3 \\
\hline \multirow[t]{3}{*}{ Sheep } & & Rams & & 3.2 & 1.7 & 4.9 & 4.1 & 1.4 & 2.2 & 4.1 & 1 & 12.8 & -7.9 \\
\hline & & Ewes & & 3.7 & 3 & 6.7 & 3.4 & 1.9 & 1.8 & 4.3 & 3.3 & 14.7 & -8 \\
\hline & & Lambs & 7.1 & 1 & 0 & 8.1 & 0 & 1 & 1.5 & 4.3 & 0 & 6.8 & 1.3 \\
\hline \multirow[t]{3}{*}{ Goats } & & Bucks & & 8.4 & 2.3 & 10.7 & 6.3 & 1.9 & 2.8 & 5.5 & 3.8 & 20.3 & -9.6 \\
\hline & & Does & & 7.6 & 3 & 10.6 & 3.8 & 2.8 & 2.5 & 5.2 & 3.5 & 17.8 & -7.2 \\
\hline & & Kids & 10.1 & 0 & 0 & 10.1 & 1.3 & 2 & 1.8 & 4.2 & 0 & 9.3 & 0.8 \\
\hline Donkeys & & & 2 & 1.4 & 1.9 & 5.3 & 1.8 & 0 & N/A & 1.4 & 1 & 4.2 & 1.1 \\
\hline
\end{tabular}

Values in italics indicate the sub-totals of the categories above

overall demographic indicators, in Table 4, which summarize the herd dynamics and production over the year. Cattle had the highest multiplication and growth rates followed by goats, sheep, then camels in that order. Cattle also had the highest mortality, offtake, commercial offtake and intake rates. Goats had the lowest mortality, offtake, commercial offtake and intake rates.

\section{Discussion}

The bias towards females seen in the herd structures, also discussed by Bailey et al. (1999) for other pastoral areas, ensures adequate provision of milk, an important source of food and income, and continued reproduction of replacement stock for rapid recovery after drought, disease or other disasters. However, in cattle, the high males to females ratio and the contrasting age trends between males and females suggest that young males were the herd fraction that was accumulated at the risk minimization stage, to be sold later at the risk absorption stage, when efforts are made to sustain the most valuable animals while selling the less valuable (Rota and Sperandini 2009).

The small steers to males ratio in cattle shows that castration is not a common practice in this pastoral

Table 3 Aggregate herd status and changes per species in Garissa County, Kenya (These figures are used in the calculation of demographic rates in Table 4 below)

\begin{tabular}{|c|c|c|c|c|}
\hline Variable/species & Camels & Cattle & Sheep & Goats \\
\hline Mean herd size, at the date of survey & 7.1 & 30.5 & 24.9 & 75.2 \\
\hline Mean entries & 14.8 & 54.6 & 19.7 & 31.4 \\
\hline Intakes & 10.7 & 45.3 & 12.6 & 21.3 \\
\hline Mean exits & 26 & 61.1 & 34.3 & 47.4 \\
\hline Offtakes & 15.3 & 36.1 & 17.3 & 27 \\
\hline Mean sales & 7.2 & 20.2 & 7.5 & 11.4 \\
\hline Mean herd size, 12 months ago & 18.3 & 31.5 & 39.5 & 91.2 \\
\hline Mean herd size over the year & 12.7 & 31 & 32.2 & 83.2 \\
\hline
\end{tabular}

Herd size 12 months ago = size at the date of survey - entries + exits. Intakes = purchases + in-donations. Offtakes = sold + out-donated + consumed. Assume mean herd size over the year $=$ (herd size to date + herd size 12 months ago)/2. Intakes are entries without births; offtakes are exits without mortalities and unexplained losses. Thus, intakes and offtakes are deliberate management entry/exit events 
Table 4 Overall livestock demographic indicators by species

\begin{tabular}{|c|c|c|c|c|}
\hline Variable/species & Camels & Cattle & Sheep & Goats \\
\hline $\begin{array}{l}\text { Annual multiplication rate (herd size at the date } \\
\text { of survey/herd size } 12 \text { months ago) }\end{array}$ & 0.39 & 0.97 & 0.63 & 0.82 \\
\hline $\begin{array}{l}\text { Annual population growth rate (annual } \\
\text { multiplication rate }-1 \text { ) * } 100\end{array}$ & $-61 \%$ & $-3 \%$ & $-37 \%$ & $-18 \%$ \\
\hline Annual production rate $(P / N)$ & -0.5 & -0.3 & -0.3 & -0.1 \\
\hline \multicolumn{5}{|l|}{$\begin{array}{l}P=\text { (herd size at the date of survey - herd size } \\
12 \text { months ago) }+ \text { (number of offtakes over the } \\
\text { year - number of intakes over the year) } N=\text { mean } \\
\text { herd size over the year }\end{array}$} \\
\hline $\begin{array}{l}\text { Annual mortality rate(probability or hazard rate for } \\
\text { an animal to die a natural death }=(\text { number died in } \\
\left.12 \text { months/herd size } 12 \text { months ago })^{*} 100\right)\end{array}$ & $50 \%$ & $69 \%$ & $32 \%$ & $16 \%$ \\
\hline $\begin{array}{l}\text { Offtake rate(probability or hazard rate for an animal } \\
\text { to exit the herd as offtake }=\text { (offtake/herd size } 12 \\
\left.\text { months ago) }{ }^{*} 100\right)\end{array}$ & $83.6 \%$ & $116.5 \%$ & $43.8 \%$ & $29.6 \%$ \\
\hline $\begin{array}{l}\text { Commercial offtake rate (sales/herd size } 12 \text { months } \\
\text { ago) }{ }^{*} 100\end{array}$ & $39.3 \%$ & $64.1 \%$ & $18.9 \%$ & $12.5 \%$ \\
\hline $\begin{array}{l}\text { Intake rate(probability or hazard rate for an animal } \\
\text { to enter the herd as an intake }=(\text { intake/herd size } \\
12 \text { months ago }) * 100)\end{array}$ & $58.5 \%$ & $143.8 \%$ & $31.9 \%$ & $23.4 \%$ \\
\hline
\end{tabular}

subsistence production. The practice is probably used as a breeding rather than a marketing tool since the greater number of the entire males enhances the reproductive potential of the herd. The high proportion of young stock in all species suggests a high birth rate or low preweaning mortality.

It is difficult to determine definite trends from the livestock herd dynamics, but one can discern efforts at culling, restocking, retention of valuable categories of animals, natural events and sometimes action that apparently had no clear explanation. However, Pavanello (2010) reported that, due to livelihood pressures, pastoralists were selling more animals than before and regardless of productivity, age or sex. Thus, there were higher entries for males than females in cattle and goats and sales were distributed among all age groups of all species including animals at their prime and valuable categories such as cattle females of 3 to 6 years of age and calves and kids.

The findings on the end balances and the negative growth rates indicate that the livestock populations would be annihilated with time if the trends were to continue and not be interrupted by year-on-year differences in population dynamics, especially the upward 'boom' phases of the livestock cycles discussed by Scoones (1996) and Bailey et al. (1999). The multiplication and growth rates are less than 1 reflecting the decrease in all species' herd sizes over the 12 months.

The herd dynamics result from the natural performance of the herd and those related to the owners' decisions, management objectives and livelihood needs. The variation in mortality rates reflected the different species' sensitivity to risk such as drought and diseases.

\section{Conclusion}

Livestock herds were structured to provide milk, replacement stock and income insurance. Goats were the main pillar of subsistence. The exit factors in the herd dynamics prevailed over the entry factors, and this was not favourable for herd re-building and maintenance. The Government should therefore intervene to smoothen livestock cycles and keep track of the dynamics.

\section{Abbreviations}

AEZ: agro-ecological zone; FAO: Food and Agricultural Organization of the United Nations; SPSS: Statistical Package for the Social Sciences.

\section{Competing interests}

The authors declare that they have no competing interests.

\section{Authors' contributions}

PMM collected the data, did the analysis and led the writing of the paper. RGW assisted in the data analysis, writing and generation of some charts. LM and PK contributed in the writing and editing. All authors read and approved the final manuscript.

\section{Authors' information}

PMM is a Senior Assistant Director at the Department of Veterinary Services, Ministry of Agriculture, Livestock and Fisheries, Private Bag-00625, Nairobi, Kenya. RGW is a Professor at the Department of Animal Production, University of Nairobi. LM is a Senior Lecturer in the Department of Land Resource Management and Agricultural Technology, University of Nairobi. PK is a Professor at the Department of Veterinary Pathology, Microbiology and Parasitology, University of Nairobi.

\section{Acknowledgements}

This study was enabled by the Eastern Africa Agricultural Productivity Project and funded by the National Commission for Science, Technology and Innovation, Kenya, and the Centre for Sustainable Dry-land Eco-systems and Societies, University of Nairobi. The authors sincerely thank the research assistants, the respondents and the Veterinary Department in the study areas for their various roles in the study. 


\section{Author details}

${ }^{1}$ Department of Veterinary Services, Ministry of Agriculture, Livestock and Fisheries, Private Bag-00625, Nairobi, Kenya. ²Department of Animal Production, University of Nairobi, P.O. Box 29053-00625, Nairobi, Kenya. 3 Department of Land Resource Management and Agricultural Technology, University of Nairobi, P.O. Box 29053-00625, Nairobi, Kenya. ${ }^{4}$ Department of Veterinary Pathology, Microbiology and Parasitology, University of Nairobi, P.O. Box 29053-00625, Nairobi, Kenya.

Received: 10 August 2015 Accepted: 3 November 2015

Published online: 23 December 2015

\section{References}

Aklilu, Y., P. Irungu, and A. Reda. 2002. An audit of the livestock marketing status in Kenya, Ethiopia and Sudan (Volume I). Community-Based Animal Health and Participatory Epidemiology Unit, Pan African Program for the Control of Epizootics, Organization of African Unity/Inter-African Bureau for Animal Resources.

Bailey, D.V., C.B. Barret, P.D. Little, and F. Chabari. 1999. Livestock markets and risk management among East African pastoralists: A review and research agenda.

FAO. 2007. The Global Plan of Action for Animal Genetic Resources and the Interlaken Declaration on Animal Genetic Resources. Adopted on 7th September 2007.

Galaty, J.R., and D.R. Aronson. 1980. Research priorities and pastoralist development: What is to be done? In The future of pastoral peoples. Proceedings of a conference held in Nairobi, Kenya, 4-8 August 1980. Commission on Nomadic Peoples, Canada; IDS/UoN, Nairobi, ed. J.G. Galaty, D. Aronson, P.C. Salzman, and A. Chouinard. Canada: IDRC.

Government of Kenya. 2008. Sessional Paper No. 2 of 2008 on National Livestock Policy. : Ministry of Livestock Development.

Kenya National Bureau of Statistics. 2010. 2009 Population and housing census highlights.

Lesnoff, M., S. Messad, and X. Juanès. 2010. 12MO: A cross-sectional retrospective method for estimating livestock demographic parameters in tropical small-holder farming systems. CIRAD (French Agricultural Research Centre for International Development). http://livtools.cirad.fr (accessed on 5th January 2012).

Pavanello, S. 2010. Livestock marketing in Kenya-Ethiopia border areas: A baseline study. London: Humanitarian Policy Group, Overseas Development Institute.

Pfeiffer, D.U. 2010. Veterinary epidemiology: An introduction, 74. West Sussex, UK: Wiley-Blackwell.

Rota, A., and S. Sperandini. 2009. Livestock and pastoralists. Livestock thematic papers, tools for project design. : IFAD.

Scoones, I. 1996. Hazards and opportunities. Farming livelihoods in dry-land Africa: Lessons from Zimbabwe. Zed Books Ltd, London and New Jersey, in association with International Institute for Environment and Development, London.

\section{Submit your manuscript to a SpringerOpen ${ }^{\circ}$ journal and benefit from:}

- Convenient online submission

- Rigorous peer review

- Immediate publication on acceptance

- Open access: articles freely available online

- High visibility within the field

- Retaining the copyright to your article

Submit your next manuscript at $>$ springeropen.com 